\title{
Does the Differential Criterion for Vesting Parental Rights and Responsibilities of Unmarried Parents Violate International Law? A Legislative and Social Study of Three African Countries
}

\author{
Julia Sloth-Nielsen*, Lorenzo Wakefield** and Nkatha L Murungi***
}

\begin{abstract}
The right to non-discrimination for all children is established in international human rights law. International children's rights law further provides for the common responsibility of parents for the maintenance of their children. African customary law and common law have always made a distinction between children born in and out of wedlock so far as the duty to maintain them is concerned. The resilience of this customary and common law approach is evident in statutory provisions of the countries discussed in this article. This is despite international obligations under children's rights treaties ratified by these countries. On the face of it, the distinction of responsibility based on marital status seems harmless. However, in view of gender inequities and resource distribution between men and women in society, such a distinction has serious implications for the rights of affected children.
\end{abstract}

\section{INTRODUCTION}

This article examines the rights and responsibilities of unmarried fathers in three African countries that have undertaken law reform: Kenya, South Africa and Namibia. ${ }^{1}$ Kenya was the first African country to develop child law in the new millennium and the legislation adopted has been controversial, with a number of decided cases arising. Initially, South Africa proposed adopting similar provisions to those of Kenya regarding the incidence of parental responsibility. Namibia adopted a dedicated act to deal with the position of children born out of wedlock. Namibia is a former South African colony and the two countries share a common law tradition.

* Professor and dean, Faculty of Law, University of the Western Cape.

* Researcher, Community Law Centre, University of the Western Cape.

*** Doctoral intern, Community Law Centre, University of the Western Cape. The authors would like to thank Prof Katharina Boele-Woelki from Utrecht University for her comments on a previous draft of this article.

1 Kenya passed the Children's Act in 2001, while South Africa passed its Children's Act in 2005. The Namibian Parliament passed a comprehensive Child Care and Protection Act in May 2011, but it has not yet come into force. 
This article starts with an exposition of the law on parental responsibility for children born out of wedlock in international law and in each of the subject countries. It explains how common concepts affecting the welfare of the child are addressed, in particular: the duty to support the child, guardianship, custody and care of the child. Themes arising from the three studies are discussed, notably the gender equality and children's rights dimensions of the law. In concluding, the authors highlight the key issues that have emerged, calling inter alia for a culturally sensitive approach to the notion of nondiscrimination in this sphere of law. It is conceded that customary law is relevant to some of the issues described. Nevertheless, in view of restrictions of space and the plurality of customary laws in the countries discussed, this article does not review relevant customary law.

\section{CHILDREN BORN OUT OF WEDLOCK IN INTERNATIONAL LAW}

The international law position, taken at face value, sets equality as the normative minimum: equality from the perspective of gender (between women and men, married women and unmarried women) and from a child rights perspective (between children born in and out of wedlock). Below are some relevant provisions of treaties ratified by the countries reviewed.

\section{Convention on the Rights of the Child (CRC)}

The CRC is the global minimum standard for the protection of the rights of children. It sets out in explicit terms the duty of states parties to ensure the CRC rights to each child within their jurisdiction without discrimination of any kind, irrespective of the child's or his or her parent's or legal guardian's race, colour, sex, language, religion, political or other opinion, national, ethnic or social origin, property, disability, birth or other status. ${ }^{2}$ States parties must further ensure that the child is protected against all forms of discrimination on the basis of the status, activities, expressed opinions or beliefs of the child's parents, legal guardians or family members. ${ }^{3}$ A state's responsibility in this regard extends to monitoring and combating discrimination against children on the basis of the marital status of their parents. ${ }^{4}$

The CRC refers to parental duties and responsibilities in various articles. ${ }^{5}$ It requires states parties to ensure that the principle of parents' common primary responsibility for the development and upbringing of children is incorporated in their respective jurisdictions, paying due regard to the best interests of the child. ${ }^{6}$ This approach does not distinguish the responsibility

2 CRC, art 2(1).

3 Id, art 2(2).

4 UN Committee on the Rights of the Child "General comment no 7" (2005 CRC/C/GC/7/Rev.1) at para 12.

5 Such as CRC arts 3, 5, 18 and 27.

6 Id, art 18(1). 
of parents on the basis of their marital status and, by extension, does not distinguish children born out of or in wedlock. The CRC regards parents' common responsibility for the upbringing of the child as a right of the child. It underscores that responsibility goes beyond financial support: both parents are to play an active role in the upbringing of children. Therefore, states parties that do not enable unmarried fathers to assume parental responsibility are likely to breach the CRC. ${ }^{7}$

\section{African Charter on the Rights and Welfare of the Child (ACRWC)}

The ACRWC prohibits discrimination of children on the basis of their “parents' or legal guardians' race, ethnic group, colour, sex, language, religion, political or other opinion, national and social origin, fortune, birth or other status". ${ }^{8}$ It also provides for the right of every child to be cared for by his parents and, as far as possible, to reside with them..$^{9}$ It vests primary responsibility for the upbringing and development of the child in the parents or other persons responsible for the child. ${ }^{10}$ The general duties emanating from parental responsibility include the duty to ensure that the best interests of the child are the basic concern at all times, and to secure living conditions necessary to the child's wellbeing. Fulfilment of this duty requires financial input. The ACRWC prohibits deprivation of maintenance on the basis of the marital status of a child's parents. ${ }^{11}$

\section{Convention on the Elimination of all forms of Discrimination against Women (CEDAW)}

CEDAW prohibits all forms of discrimination against women. States parties are obliged to ensure, on the basis of equality, that men and women have the same rights and responsibilities over their children, irrespective of their marital status. It stipulates that the best interests of the child are to be paramount. ${ }^{12}$ In light of article 1 of CEDAW it is hoped that, by giving equal rights and responsibilities to men and women, substantive equality will be attained. It has therefore been argued that, although the definition of discrimination under article 1 of CEDAW does not give an "explicit definition or theoretical basis of equality", its "emphasis on the impact of discrimination can be read as favouring substantive equality".13

7 UNICEF Implementation Handbook for the Convention on the Rights of the Child (3rd ed, 2007, UNICEF at 235.

8 ACRWC, art 3.

9 Id, art 19.

10 Id, art 20(1).

11 Id, art 18(3).

12 CEDAW, art 16(d).

13 E Bonthuys and W Domingo "Constitutional and international law context" in C Albertyn and E Bonthuys (eds) Gender Law and Justice (2007, Juta) 51 at 61 (emphasis original). 


\section{Protocol to the African Charter on Human and Peoples' Rights on the Rights of Women in Africa (AWP)}

The AWP was adopted following the realization that, despite the ratification of CEDAW by many African states, women in Africa continued to experience discrimination. It was proposed to mobilize political will. ${ }^{14}$ The AWP addresses the obligation of states parties to ensure the equality of obligations of parents for the upbringing of their children, but only in the context of marriage and separation. ${ }^{15}$ It does not contain any provisions relating to parents of children born out of wedlock.

\section{CHILDREN BORN OUT OF WEDLOCK IN KENYAN LAW}

\section{Historical background}

Before 2001, the law relating to children in Kenya was found in several statutes, but primarily in the Guardianship of Infants Act, the Children and Young Persons Act, and the Adoption Act. ${ }^{16}$ The Guardianship of Infants Act addressed matters of guardianship and the custody of unmarried persons below the age of 18 years. ${ }^{17}$ The Children and Young Persons Act primarily made provisions for the protection and discipline of children, juveniles and young persons. ${ }^{18}$ English common law was, and continues to be, a source of law in Kenya. Kenya ratified the CRC and the ACRWC in 1990 and 2000 respectively. The adoption of the Children's Act 2001 was therefore partly driven by the need to update the law to reflect the obligations under these and other international conventions.

\section{The Children Act $2001^{19}$}

This act is the principal statute to give effect to the CRC and ACRWC in Kenya. ${ }^{20}$ It provides for, inter alia, parental responsibility, fostering, adoption, custody, maintenance, guardianship, care and protection of children. Since its adoption, some of the issues have elicited public debate and litigation. The provisions on children born out of wedlock constitute one such issue. The act is founded upon a sound principle of non-discrimination in the rights of children. ${ }^{21}$ It does not seem to distinguish between children on the basis

14 F Banda "Blazing a trail: The African Protocol on Women's Rights comes to force" (2006) 50/1 Journal of African Law 72 at 72-73.

15 See AWP, arts 6 and 7. In art 6(i), in respect of marriage, the AWP requires equal rights of the man and woman to contribute jointly to the interests of the family, and the protection and education of their children. In the event the marital relationship ends, art 7(c) requires reciprocal responsibilities of both men and women towards their children.

16 Chaps 144, 141 and 143 of the Laws of Kenya respectively (all now repealed).

17 Guardianship of Infants Act, preamble.

18 Children and Young Persons Act, preamble.

19 Act 8 of 2000.

20 Id, preamble.

21 Id, sec 5. 
of the marital status of their parents, save insofar as the subject of parental responsibility is concerned. The act does create a different criterion for the acquisition of parental responsibility for the father of a child born out of wedlock from that of a child born in wedlock. These provisions on parental responsibility for children born out of wedlock have been criticized as falling short of international standards and thus as discriminatory against such children. This assertion is explored further below.

\section{Incidence of parental responsibility under the Children Act}

The definition of parental responsibility, the duties arising from it and its legal incidence are addressed in part III of the act. Section 23 provides that parental responsibility refers to "all duties, rights, powers, responsibilities and authority which by law a parent of a child has in relation to the child and the child's property in a manner consistent with the evolving capacities of the child". ${ }^{22}$ Where both parents were either married at the time of the birth of the child or have subsequently married, they acquire automatic and equal parental responsibility over the child. ${ }^{23}$ However, where parents were not married at the time of the child's birth and have not subsequently done so, parental responsibility for the child vests in the mother in the first instance. ${ }^{24}$ The father may only acquire responsibility if he fulfils one of the following five conditions:

(a) he applies to court for an order vesting parental responsibility in him;

(b) he enters an agreement with the mother of the child giving him parental responsibility;

(c) he cohabits with the mother for a period or periods of at least 12 months;

(d) he has acknowledged paternity; or

(e) he has maintained the child. ${ }^{25}$

The act thus draws a clear distinction between the incidences of parental responsibility for fathers of children born in and out of wedlock. Not so for the mother: her parental responsibility accrues automatically by virtue of giving birth to the child. In terms of the act, parental responsibility is a function of parental status. Further, the duty to support the upbringing of the child is dependent upon the acquisition of parental responsibility. The ramifications of this are discussed below.

\section{Parental responsibility of unmarried fathers}

The approach of the Children Act to the parental responsibility of unmarried fathers raises issues that are relevant to the rights of the child. First, unlike the

22 Id, sec 23(1).

23 Id, sec 24(1)-(2).

24 Id, sec 24(3).

25 Id, sec 25. 
mother, the father of such a child does not automatically acquire responsibility. Secondly, the ways in which the father of the child may acquire responsibility all demand a positive step from him and are therefore subject to his discretion. In addition, the provision ostensibly does not leave room for interested third parties, the mother of the child, or the child to enforce parental responsibility against such a father. In this way, the act entrenches the discretion of the father as to whether or not to assume responsibility. The effects of these provisions on the rights of the child are relevant to the determination of whether the law in effect discriminates against a child born out of wedlock. This article will now examine this issue in relation to the duty of support, guardianship, custody, and care and control.

\section{Duty of support}

The bearer of parental responsibility under the act has a duty to maintain the child and, in particular, to provide the child with food, clothing, shelter, medical care and education. ${ }^{26}$ This means that the duty to maintain the child is subject to the establishment of parental responsibility. ${ }^{27}$ Maintenance is a component of parental responsibility and cannot, according to the act, be inferred independently.

The act provides that the absence of responsibility does not "affect any obligation which [a] person might have in relation to the child", such as the statutory duty to maintain the child. ${ }^{28}$ It is not clear what is meant by "statutory duty" in this section. Since the act is the comprehensive law dealing with the maintenance of children, the reference to "statute", at least so far as the unmarried father is concerned, implies statutes other than the act. However, the only other law likely to affect the duty of parents to maintain their children is the law relating to matrimonial proceedings, which is obviously inapplicable to unmarried parties.

Section 90 of the act provides for how maintenance is to be executed. In respect of unmarried parents, section $90(\mathrm{e})$ of the act provides that, where the father has acquired parental responsibility, he has a duty to maintain the child jointly with the mother. This section does not address the obligation of the unmarried father who does not seek, or has not acquired, parental status. The omission of the unmarried father from section 90(e) is fatal to these children's access to maintenance. On this basis, it can be argued that the unmarried father has no legal duty to support his child financially, and there is no legal ground for a maintenance claim to be made against him. ${ }^{29}$

This was partly the argument of the applicants in the RM and Another $v$ Attorney General. ${ }^{30}$ The court's attempt to respond to this issue was

26 Id, sec 23(2).

27 MN Wabwile "Rights brought home? Human rights in Kenya's Children Act, 2001" International Survey of Family Law (2005, ISFL) 393 at 399-400.

28 Children Act, sec 23(4)a.

29 Wabwile "Rights brought home?", above at note 27 at 410.

30 RM and Another $v$ Attorney General (2008) KLR (gender and family) 574. The applicant was the mother of a child born out of wedlock, although the mother and father were living 
unsatisfactory. While arguing that the needs and interests of the child were paramount, overriding the marital status of the parents, the court also stated that the provision was meant to avoid a situation that allowed the mother of the child to "point at the nearest man in the street and baptise him a father of the child without according him a right of hearing or producing proof of paternity". ${ }^{31}$ This interpretation conveys an underlying policy of protectionism towards the father, without due regard for the welfare of the child born out of wedlock, and replays perceived unequal power relations between men and women in society.

Fundamentally, the act thus shields the father from child support obligations. ${ }^{32}$ This is not to suggest that enjoining the unmarried father to pay child support alone would satisfy all the requirements of parental responsibility; nevertheless, the driving factor behind the call for unmarried fathers to have parental responsibility is so that they can provide financial support for the child (as opposed to acquiring rights towards the child). By failing to establish an explicit duty to maintain the child as a legal issue independent of parental responsibility, the act fundamentally compromises the child's right to access maintenance.

Section 6 of the act establishes the right of every child to "live with and be cared for by his parents" (emphasis added). In terms of section 22(1) of the act, if any person alleges that any of the provisions of sections 4 to 19 (inclusive) has been, is being or is likely to be contravened in relation to a child, they may apply to the High Court for redress on behalf of the child. Is the unmarried father's failure to take up responsibility in respect of a child a breach of section 6 ?

The High Court of Kenya in MW $v K^{33}$ interpreted the duty of care under section 6 as follows:

"Protection of the law in my view includes the right of the child to realize the benefits conferred by the Act which are specifically set out in part II ... If the child cannot enjoy proper parental upbringing, healthcare, and good education because the child was born out of wedlock, and because the putative father has denied paternity ... then the provisions of the Act affording the

contd

together at the time of the birth. The father of the child had paid the hospital expenses for the birth and performed other customary rituals on the baby. However he disappeared when the child was approximately four months old. The mother challenged section 24(3) of the act arguing that it was discriminatory and violated the CRC, the ACRWC and the 1963 Kenyan Constitution because it disadvantaged her child compared to children with married parents.

31 Id at 589.

32 MN Wabwile "Rights brought home?", above at note 27 at 399.

33 MW $v$ KC 2005 eKLR, available at: <http://www.kenyalaw.org/CaseSearch/case_search_ one.php?pageNum_result=38\&totalRows_result $=455 \&$ casParties $=\&$ casSubject=rights\&cas Number $=\&$ casCourt $=\&$ casjudges $=\&$ casType $=\&$ casAdvocates $=\&$ casCitation $=\&$ casYear $=\&$ che ck_submit=1\&submitter=Searching> (last accessed 20 June 2011). 
child protection become a dead letter unless the courts are prepared to compel putative fathers to undergo a DNA test to determine paternity."

The court was further of the opinion that, to secure an order for DNA testing of a defiant father (as was sought by the applicant), the applicant was required to prove inter alia that the father's refusal to take the test had deprived the child of the enjoyment of the rights and benefits enshrined in the act. The reasoning of the court in this case seems to provide a further avenue for mothers of children born out of wedlock to pursue support from the father of the child. The section does not however resolve the need for the mother to initiate a costly court process in order to access financial support. The optimum position is to establish a duty of support for both parents from the outset to avoid the need to litigate.

\section{Guardianship}

Guardianship is covered in part VIII of the act. The act defines a guardian as a person appointed by will or deed by a parent or by a court to take parental responsibility over the child upon the death of the parent. ${ }^{34}$ The guardian may act alone or jointly with a surviving parent. ${ }^{35}$ The guardian need not be the custodian of the child where he is only appointed over the estate of the child. ${ }^{36}$ The father of a child born out of wedlock may only appoint a guardian in respect of that child if he has acquired parental responsibility. ${ }^{37} \mathrm{He}$ is however eligible to be appointed guardian.

\section{Custody}

Custody in the act refers to parental rights and duties relating to possession of the child as conferred by a custody order. ${ }^{38}$ It can vest in a parent, guardian or other person (with the consent of the parent or guardian where such person has stayed with the child for at least three months preceding the application), ${ }^{39}$ or by any other person if that person can show cause why s/he should be granted custody. An unmarried father is thus entitled to apply for custody, whether or not he has taken up parental responsibility over the child. It also implies that custody and guardianship are independent concepts under the act.

\section{Care and control}

Before the adoption of the act, the concept of care and control of children did not feature in the law relating to children. As currently understood, care and control of a child refers to the "actual possession and control of the child", ${ }^{40}$ or

\footnotetext{
34 Children Act, sec 102(1)

35 Ibid.

36 Id, sec 102(5).

37 Id, sec 102(1)

38 Id, sec 81(a).

39 Id, sec 82(2).

40 Id, sec 81(b).
} 
factual custody. ${ }^{41}$ It does not confer rights on the bearer but it creates the duty to take reasonable steps to safeguard the welfare and interests of the child. ${ }^{42}$

\section{Analysis of gender equality}

In terms of the Children Act, the mother of a child born out of wedlock does not have the capacity to enforce the father's responsibility for the child. The possibility of entering into a parental responsibility agreement with the father exists, but this is dependent upon the willingness of the father, and he can decline to co-operate. Ultimately, the mother's power to enforce the father's responsibility must draw from either section 23 (read with section 25) or section 90 (read with section 91).

As detailed above, it is not possible to pressure the father into taking up responsibility under section 25 . Section $90(\mathrm{e})$ on the other hand presumes that an unmarried father is not responsible for the maintenance of the child. Section 91 talks of the court's power to "determine any matter relating to the maintenance of the child" and to make maintenance orders. However it appears that this provision is intended to address "matters relating to maintenance" in respect of those who already have such responsibility. The sequence of the sections further suggests that the presumption in section 90, including section 90(e), informs the subsequent provisions.

Besides, to expect the court to determine the existence of a duty to maintain the child under section 91 would be tantamount to requiring the court to determine the incidence of parental responsibility. This is certainly beyond the ambit of section 90. In effect then, the mother of a child born out of wedlock is powerless against the father to enforce parental responsibility. In a similar vein, she cannot stop the father from acquiring parental responsibility when he so wishes. While she may decline to enter a parental rights agreement, decline maintenance for the child or oppose an application for responsibility lodged by the father, she is helpless against him if he acknowledges paternity of the child. She, by contrast, has no choice as to whether to take up responsibility because it attaches by virtue of her delivery of the child. The gendered inequality of her position is therefore obvious.

Regarding the father, acquisition of parental responsibility is a function of actions which he can "conveniently avoid or actively evade". ${ }^{43}$ Any acknowledgement of paternity or indication of intention to be involved in the development of the child confers the father with automatic parental status. In Kenya, payment of child support as part of parental responsibility thus remains a possible disincentive for a father to take up responsibility.

41 Id, sec 81(d).

42 Id, sec 81(3).

43 MN Wabwile "Child support rights, discrimination, illegitimate father; testing the constitutionality of the Kenya Children's Act" (unpublished paper on file with the authors, 2007) at 6. 


\section{Point of contention}

If the duty of support was not tied to the incidence of parental responsibility, then the demand for unmarried fathers to assume responsibility might dissipate. The main driver behind the call for the establishment of a duty of support independent of parental responsibility is the need to ensure that unmarried fathers contribute to the maintenance of their children without the choice of exempting themselves. It has been argued that the push for fathers to assume responsibility is ironic, since in other jurisdictions, especially in developed countries and in some developing ones such as South Africa, the debate is rather driven by fathers of children born out of wedlock seeking to acquire responsibility over the child. ${ }^{44}$ Whereas this argument is fundamentally true, the two situations should not be compared as though they were similar. These jurisdictions treat the duty to support the child differently: the distinguishing factor is that the father's duty to maintain the child exists independently from the assignment or acquisition of parental status.

\section{An issue of discrimination?}

In RM and Another $v$ Attorney General, the High Court of Kenya had the opportunity to determine whether section 23(3) of the Children Act discriminated against children born out of wedlock. The applicant argued that, by vesting all parental responsibility upon the mother, the section discriminated against both the mother and the child; the father could choose to assume responsibility for the child or not, but that choice was not available to the mother. The court found that the differentiation made under the section did not amount to discrimination under Kenya's then constitution. ${ }^{45}$ The High Court sidestepped the issue, relying on international instruments in support. ${ }^{46}$

The court regarded the differentiation in the act to be within the state's "margin of appreciation" in the domestication of international legal instruments. Unfortunately, this can be interpreted as a tacit recognition that the act falls short of international standards. Because the duty to maintain the child is pegged to the presence of parental responsibility, the act compromises the capacity of children born out of wedlock to access child support from their fathers on an equal basis with children born within marriage. In effect, such

44 In response to a request to amend section 24 of the act, it was argued that it was ironic that, in some jurisdictions, the struggle is being waged by fathers who consider the law discriminatory and fight for an easier route to acquire parental responsibility (usually against reluctant mothers). In Kenya, it is mothers fighting reluctant fathers: "Drafter's report on proposals for the amendment of the Children Act (CAP 586 Laws of Kenya)" (on file with the authors) at 9.

45 The High Court subsequently criticized the finding on non-discrimination. See the dictum of Lady Justice Martha Koome in JGM $v$ CNW (2008) eKLR 6.

46 A Skelton "The development of a fledging child rights jurisprudence in Eastern and Southern Africa based in international and regional instruments" (2009) 2/9 African Human Rights Law Journal 482 at 489. 
children are substantively discriminated against in access to parental care. Hence, it is suggested that the differential treatment of legitimate and illegitimate children does not meet international children's rights standards. The "margin of appreciation" accorded the state cannot be so widely construed as to defeat a principle as fundamental as that of non-discrimination. In light of the socio-economic inequalities between men and women in Kenya, the failure to entrench a duty of the father to contribute financially to the upbringing of the child born out of wedlock compromises the substantive equality of children. The act must therefore be deemed discriminatory. The state is under a duty to eliminate conditions that cause or help to sustain such discrimination. ${ }^{47}$

\section{The impact of Kenya's new Constitution}

Kenya's 2010 constitution ${ }^{48}$ heralds a new dispensation for the human rights of children. Under article 53(1)(e), every child has a right to parental care and protection, which includes equal responsibility of the mother and the father to provide for the child whether they are married to each other or not. In literal terms, the provision does not affect the incidence of parental responsibility. Rather, it implies an intention to sever the duty to maintain the child from the package of parental responsibility. However, until the Children Act is amended appropriately, the enforcement of the constitutional provision could vest automatic parental responsibility in the unmarried father. This is because, under the Children Act, maintenance of the child is one of the ways in which an unmarried father can acquire parental responsibility over the child. ${ }^{49}$ Article 53(1)(e) of the new constitution can by default then mean that every father now has automatic parental responsibility over his children. Whereas this would put Kenyan law on a similar footing with the laws of many other countries in so far as maintenance is concerned, it may have the absurd effect of giving absentee parents (especially unmarried fathers) rights over children that have the potential to impact negatively on their wellbeing.

The new constitution is likely to trigger enormous legislative reform to align existing statutes with the new regime. ${ }^{50}$ Entrenching the duty to provide for the child, notwithstanding the parents' marital status, is by far one of the greatest gains for child rights advocates in Kenya; it must be followed as soon as possible by a review of the provisions of the Children Act to avoid absurd results.

47 UNICEF Implementation Handbook, above at note 7 at 235.

48 On 4 August 2010 Kenya voted to adopt a new constitution.

49 Children Act, sec 25(2).

50 Under art 2(4) of the new constitution, any law which is inconsistent with the constitution is void to the extent of such inconsistency. If the legislature does not undertake law reform, the provisions of the act will therefore be challengeable in the Constitutional Court. 


\section{CHILDREN BORN OUT OF WEDLOCK IN SOUTH AFRICAN LAW}

\section{Historical background}

In South African Roman-Dutch common law, parental rights and responsibilities were known as parental "authority and power". ${ }^{51}$ Parental authority was formally defined as: "the rights, powers, duties and responsibilities parents have in respect of their minor children and those children's property". 52 This parental authority and power consisted of guardianship, custody and access. Guardianship traditionally vested in fathers where children were born to married parents. Custody entailed that "custodian parents [had] the rights to direct the daily living arrangements of a child, including secular, religious and cultural education, to determine the child's associates and to administer appropriate discipline". ${ }^{53}$ Parental authority and power "was automatically conferred on both parents of a "legitimate' child ... and on the mother of an 'illegitimate' or extra-marital child". ${ }^{54}$

The Guardianship Act 192 of 1993 (now repealed) gave both parents of a child born in wedlock shared guardianship over their child; it also vested guardianship upon the unmarried mother (only) of a child born out of wedlock.

The position was thus discriminatory towards unmarried fathers, who had no automatic rights regarding their biological children, although they were permitted at common law (reaffirmed in a string of decisions) to approach the High Court for the allocation of guardianship, custody or access. The unequal treatment of unmarried fathers led to a movement in South Africa to re-examine their rights and responsibilities, in the light of the new constitutional dispensation (since 1994) which promoted equality, proscribed unfair discrimination on a range of listed grounds, and enshrined the child's right to parental care. The first major, post-constitution challenge by an unmarried father was in Fraser $v$ The Children's Court, Pretoria North and Others 55 where the applicant (an unmarried father) insisted on exercising some form of parental rights and responsibilities in the context of the adoption, without his consent, of his child who had been born out of wedlock. ${ }^{56}$ Parliament was ordered to adopt legislation that would grant unmarried fathers more rights. Parliament thereupon enacted the (inelegantly named) Natural Fathers of Children Born out of Wedlock Act (NFCBWA), ${ }^{57}$ which permitted unmarried

51 PQR Boberg The Law of Persons and the Family (1977, Juta) at 458.

52 DSP Cronje and J Heaton South African Family Law (2nd ed, 2004, Butterworths) at 265.

53 E Bonthuys "Parental rights and responsibilities in the Children's Bill 70D of 2003" (2006) 3 Stellenbosch Law Review 482 at 483.

54 J Heaton "Parental responsibilities and rights" in CJ Davel and A Skelton (eds) Commentary on the Children's Act (2007, Juta) 3-1 at 3-3.

551997 (2) SA 261 (CC).

56 In this case the applicant applied to have sec 18(4)(d) of the then Child Care Act, which allowed for only the mother's consent, to be declared unconstitutional. The Constitutional Court found this section to discriminate on the basis of marital status. 
fathers to bring an application to the High Court in order to have parental authority and power conferred upon them. ${ }^{58}$ Section 2(5) of this act stipulated certain factors a court would have to take into account when considering any such application.

The NFCBWA thus attempted to rectify (to a limited extent) the lack of acknowledgement of the role of unmarried fathers in the lives of their children. It did this by providing expensive and time consuming remedies to such fathers, financially out of the reach of many. Arguably, the law as it stood did very little to comply with international instruments ratified by South Africa at that time. ${ }^{59}$

\section{Development of the South African Children's Act}

South Africa undertook a lengthy process of developing comprehensive new legislation on child protection. The South African Law Reform Commission (SALRC), spearheading the investigation, also dealt with the issue of parental responsibilities and rights, including those aspects relating to the responsibilities and rights of unmarried fathers.

The SALRC acknowledged that unmarried fathers should "be able to obtain parental responsibility or certain components thereof by making application to court and satisfying such court that this will be in the best interest of the child". ${ }^{60}$ Going further than the NFCBWA, however, the SALRC recommended that unmarried fathers who fall into one of the following categories should automatically be vested with parental responsibilities, without the need for an application to court:

“(a) the father who has acknowledged paternity of the child and who has supported the child within his financial means;

(b) the father who, subsequent to the child's birth, has cohabited with the child's mother for a period or periods which amount to not less than one year;

(c) the father who, with the informed consent of the mother, has cared for the child on a regular basis for a period or periods which amount to not less than one year, whether or not he has cohabited with or is cohabiting with the mother of the child." 61

In their search for a suitable model, they borrowed from the Kenyan Children Act, which had stipulated five ways in which an unmarried father could acquire parental rights and responsibilities, as discussed above, including the 12 month cohabitation criterion.

58 Secs 2(1) and (2).

59 South Africa ratified the CRC in 1995, the ACRWC in 2000, CEDAW in 1997 and the AWP in 2005.

60 SALRC Review of the Child Care Act Report (2002, Project 110) at 64-67.

61 Id at 65. 
When the South African Children's Act ${ }^{62}$ was tabled in Parliament, a significant debate ensued around the formulation of the section on the parental responsibilities and rights of unmarried fathers. Arguments were raised by family law practitioners and the feminist lobby. The former raised the practical difficulties in applying the Kenyan provision of calculating when the father cohabits with the mother for "a period or periods of at least 12 months". Feminists argued that the proposal would give men the power to decide what periods constitute 12 months. Organizations argued that the time provisions would give rise to a "potential minefield of factual disputes". ${ }^{63}$ However pressure groups like "Fathers 4 Justice" threatened further constitutional attack if the provisions of the NFCBWA were not improved: awarding parental responsibilities and rights to unmarried fathers had to occur more automatically, and could not rest on court applications alone. Parliament too was mindful of the constitutional risks of not addressing the position of unmarried fathers. The text of section 21 of the Children's Act was finally agreed.

\section{Acquiring parental responsibilities and rights by unmarried fathers}

Section 21 of the Children's Act, which came into effect on 1 September $2007,{ }^{64}$ stipulates that:

“(1) The biological father of a child who does not have parental responsibilities and rights in respect of the child in terms of section 20 , acquires full parental responsibilities and rights in respect of the child

(a) if at the time of the child's birth he is living with the mother in a permanent life-partnership; or

(b) if he, regardless of whether he has lived or is living with the mother

(i) consents to be identified or successfully applies in terms of section 26 to be identified as the child's father or pays damages in terms of customary law;

(ii) contributes or has attempted in good faith to contribute to the child's upbringing for a reasonable period; and

(iii) contributes or has attempted in good faith to contribute towards expenses in connection with the maintenance of the child for a reasonable period."

As can be read, the final product has not provided that specific time periods of cohabitation or care are taken into account when vesting an unmarried father

62 Act 38 of 2005.

63 D Smart "Written submission on the Children's Bill" (on file with the authors, 2004) at 1.

64 A few sections of the act (most of the first three chaps and a few other provisions) were put into operation on this date. The remainder of the act came into force on 1 April 2010. The reasons for the dual dates are complex and lie beyond the scope of this article. 
with parental responsibilities. The changes brought about do not fully address some concerns, as the final provision stipulates that, if an unmarried father either lived with the mother of his child in a permanent life-partnership at the birth of the child or has contributed for a reasonable time, he acquires full parental responsibilities and rights over the child automatically. ${ }^{65}$ First, it should be noted that "a permanent life-partnership" may be defined by somewhat subjective criteria, which can lead to dispute. Secondly, there may be varying interpretations of contributions "for a reasonable period"; thirdly, an interpretation problem might also arise: by placing the word "and" between requirements (ii) and (iii) of section 21(1)(b), it is arguable that the legislature signifies that all three section 21 (b) requirements must be met before a father can acquire parental responsibilities and rights automatically by fulfilling these criteria. ${ }^{66}$ The interpretation of these provisions has not yet been contested in court.

\section{Terminology}

The common law used terminology that was not focused on the best of interests of children, but on the interests of parents. Furthermore, common law and statute alike classified children depending on whether their parents were married or unmarried. This, in effect, led to the discriminatory position of children born out of wedlock. The Children's Act does not distinguish children by reference to the marital status of their parents at all, adopting language that is "child neutral", and differentiating only between married mothers and unmarried mothers, and married fathers and biological fathers.

\section{Guardianship}

The Children's Act retained the concept of guardianship, which is defined by reference to a finite set of functions in section 18(3). ${ }^{67}$ Where a parental rights and responsibilities agreement involving unmarried fathers concerns conferral (or amendment or termination) of guardianship, section 22(7) requires that only the High Court may be approached.

\section{Care and contact}

Two further elements of parental responsibilities and rights are care and contact. Before the enactment of the Children's Act, care and contact were known

65 It has been confirmed that this provision has retrospective effect, thereby impacting many fathers who acquired rights instantly upon promulgation of the act.

66 A Skelton "Parental responsibilities and rights" in T Boezaart (ed) Child Law in South Africa (2009, Juta) 62 at 76.

67 Sec 18(3) stipulates that a guardian of a child must: “(a) administer and safeguard the child's property and property interest; (b) assist or represent the child in administrative, contractual and other legal matters; or (c) give or refuse any consent required by law in respect of the child, including - (i) consent to the child's marriage; (ii) consent to the child's adoption; (iii) consent to the child's departure or removal from the Republic; (iv) consent to the child's application for a passport; and (v) consent to the alienation or encumbrance of any immovable property of the child." 
as "custody" and "access", but "care" and "contact" are much broader than "custody" and "access". The definition of "care" in section 1 elaborates a range of means by which a child's rights to growth, wellbeing and development should be fulfilled by those having responsibility for a child. These include physical aspects such as providing a place for the child to live, as well as a range of psychosocial functions and maintenance of the child.

Access to a child usually meant the parent's right to visit a child. "Contact" in the act refers to a much more innovative concept which aims overall at maintaining a personal relationship with the child and, if the child lives with someone else, regular communication through various means, including electronic communication.

\section{Duty of support}

Maintenance is regulated by the Maintenance Act 99 of 1998 and not the Children's Act. Nevertheless, multiple features of maintenance are filtered into parental responsibilities and rights in the latter act.

Section 21(2) of the Children's Act stipulates that an unmarried father's acquisition of parental responsibilities and rights does not affect the duty of that father to provide maintenance. Yet, at the same time, section 21(1)(b) (iii) requires that a father must have contributed or attempted to contribute to the maintenance of the child in order to acquire automatic parental rights and responsibilities. Even though acquiring parental rights and responsibilities is not dependent on the payment of maintenance alone, it is clear from the act that it is a factor to be considered. Therefore maintenance and parental responsibilities and rights are complementary in nature.

The foreseeable contention in section 21(1)(b)(iii) relates to the interpretation of "contributed", "attempted to contribute" and "reasonable period". The act does not define these or suggest the levels of "contribution" or required efforts at "attempting to contribute for a reasonable period"; these may be subjective, depending on which parent might stand to benefit. Heaton is of the view that, if an unmarried father has partly complied with a maintenance order, he could qualify for full parental rights and responsibilities. ${ }^{68}$

A duty of support would also rest on the paternal grandparents where an unmarried father cannot maintain a child. In Petersen $v$ The Maintenance Officer, Simonstown Maintenance Court and Others, ${ }^{69}$ the applicant averred that the paternal grandparents of a child are legally liable to pay maintenance, where the unmarried father is not in a position to pay. Previously, Motan and Another $v$ Joosub $b^{70}$ had found that no duty of support existed between paternal grandparents and their illegitimate grandchildren. This was argued to be discriminatory against illegitimate children and therefore

68 J Heaton "Parental responsibilities and rights", above at note 54 at 3-12.

$692004(2)$ SA 56 (C).

$701930 \mathrm{AD} 61$. 
unconstitutional. The High Court agreed, finding that the "common law rule which differentiates between children born in wedlock and extra-marital children, not only denies extra-marital children an equal right to be maintained by their paternal grandparents, but conveys the notion that they do not have the same inherent worth and dignity as children who are born in wedlock". ${ }^{71}$ One question stemming from this case is whether a father can claim parental responsibilities and rights where he does not maintain the child, but the support is provided by his parents. From a plain reading of section 21, the answer would be no, as the section requires the father to contribute or attempt to contribute.

\section{Avoiding controversy}

A new provision of the Children's Act (section 22) provides for a mother who has parental responsibilities and rights to enter into an agreement with a biological father who has not otherwise acquired such rights, in order to confer these upon the father. That agreement is then registered in order to take effect. The agreement must be confirmed by the office of the family advocate, ${ }^{72}$ a specialized governmental section which advises divorce courts (and now fulfils functions vis-à-vis unmarried parents) on the child's best interests in private law litigation. Section 29 of the act stipulates that a family advocate can only register a parental responsibilities and rights agreement if it is in the child's best interests.

One explanation as to why there has not yet been litigation around section 21(1)(b) (which establishes the criteria for the automatic acquisition of rights for unmarried fathers) lies in the compulsory mediation provision of section 21(3). In the case of a dispute as to whether the conditions in section 21(a) or (b) have been fulfilled, mediation between unmarried parents is required. A family advocate, social worker or other suitably qualified person would assist unmarried parents in coming to an amicable solution in the child's best interests. ${ }^{73}$

The new dispensation provides a more gender equal position than previously prevailed. Not only can a High Court application be avoided, but some unmarried fathers now gain automatic recognition as bearers of parental responsibilities and rights. Further, they can be assigned parental rights by agreement with the mother of the child. They can also, as in the past, apply to court, but this is also to an extent simplified: section 23(1) of the Children's Act stipulates that "any person having an interest in the care, well-being or development of a child may apply to ... the children's court for an order granting to the applicant ... (a) contact with the child; or (b) care of the child". Hence, save where guardianship is involved, the children's court at district level can be utilized, a much less expensive and more accessible option.

\footnotetext{
71 Id, para 19.

72 Established in terms of the Mediation in Certain Divorce Matters Act 24 of 1987.

73 Children's Act, sec 21(3)(b).
} 


\section{Analysis of equality}

Section 21 of the Children's Act attempts to promote a greater level of formal equality between married and unmarried parents, provided that certain criteria are met. However, whether the legislative answer is the correct solution and whether it is fair to both mother and unmarried father is still hotly debated. It must be born in mind that the final draft of section 21 became a negotiated solution during parliamentary debates.

Because the obligation to maintain a child is not linked exclusively to an unmarried father having parental responsibilities and rights, it is likely that the duty to maintain a child will often serve as a reason for unmarried fathers also to insist on having parental responsibilities. But if unmarried fathers do not pay maintenance, mothers would rightfully still insist on child support, even though unmarried fathers do not enjoy parental responsibilities and rights. In Bannatyne $v$ Bannatyne, Mokgoro J eloquently highlighted important social assumptions underlying the payment of maintenance and the position in which most unmarried mothers in South Africa find themselves: "[d]ivorced or separated mothers accordingly face the double disadvantage of being overburdened in terms of responsibilities and under-resourced in terms of means. Fathers, on the other hand, remain actively employed and generally become economically enriched. Maintenance payments are therefore essential to relieve this financial burden". ${ }^{74}$

\section{CHILDREN BORN OUT OF WEDLOCK IN NAMIBIAN LAW}

\section{Historical background}

Namibia achieved independence in 1990 after a long war with South Africa. 30 years later, the legal system is still characterized by a complicated mix of preand post- independence law, including Roman-Dutch common law inherited from South Africa, statutory law from both the pre-independence and postindependence period, customary law and an over-arching constitution based on human rights. As Hubbard and Cassidy note, the Namibian Constitution "is one of the few Constitutions in the world that uses gender neutral language throughout, and it explicitly forbids discrimination on the basis of sex. It explicitly provides for equality in all aspects of marriage and gives special emphasis to women in the provision which authorizes affirmative action". ${ }^{75}$ The majority of Namibians live according to customary law, ${ }^{76}$ protected under section 66 of the constitution to the extent that customary law does not conflict with the constitution or any other legal statute.

74 Case CCT 18/02, Constitutional Court 2002 at para 29.

75 D Hubbard and E Cassidy "Family law reform in Namibia: Work in progress" in A Bainham (ed) The International Survey of Family Law (2002, Jordan Publishing) 255 at 255.

76 L Ambunda and W Mugadza "The protection of children's rights in Namibia: Law and policy" in O Ruppel (ed) Children's Rights in Namibia (2009, Macmillan Education) 5 at 16. 
In 1996 Namibia amended inherited laws which permitted discrimination in family relations. The Married Persons Equality Act 1 of 1996 introduced equal guardianship powers for married mothers and fathers, overriding the common law position that only the father was the guardian of a child born in wedlock. ${ }^{77}$ Section 14(2) provided that mothers and fathers could exercise their guardianship powers concurrently, save in certain statutorily defined instances where the consent of both parents is required. Thereafter, the Children's Status Act 6 of 2006, in force since 3 November 2008, brought about legislative changes to the position of unmarried parents. However, magistrates have recommended revisions to this act due to problems concerning its implementation. ${ }^{78}$ In May 2011, the Namibian Parliament passed the Child Care and Protection Act (2010); when enacted, this will constitute a comprehensive children's law intended to give effect to obligations incurred under the CRC and ACRWC,79 and to modernize Namibian statutory law. ${ }^{80}$ The new act will also partially address concerns raised in connection with the Children's Status Act.

\section{Acquisition of parental responsibility}

Under Namibian common law, as in South Africa, marital inequality was entrenched (until the Married Persons Equality Act of 1996), as was discrimination on the grounds of illegitimacy. Since the legislative intervention noted above, married mothers and fathers now share parental responsibilities, still termed access, custody and guardianship.

Under common law, only the mother of a child born outside marriage automatically acquired parental responsibility for that child. Unmarried fathers had no parental authority, although the father of a child did bear a duty of support.

The developments in South African case law and the NFCBWA postdate Namibian independence. Therefore, the first attempt to address the issue of illegitimate children in Namibia came about through statute. However, in Frans $v$ Paschke and Others, ${ }^{81}$ the Namibian High Court declared unconstitutional the common law rule barring children born outside marriage from inheriting intestate from their fathers. ${ }^{82}$

The Children's Status Act governs the acquisition of parental rights for children born outside marriage only. Its passage through Parliament was controversial and hotly debated: it took three full years to pass. The final provisions

77 This had been achieved three years earlier in South Africa via the Guardianship Act 1993 (now repealed).

78 At a workshop for all Namibian magistrates held in September 2009 in Swakopmund.

79 Namibia ratified the CRC in 1990 and the ACRWC in 2004

80 The South African Children's Act 33 of 1960 is still the governing statute for welfare proceedings, adoption, residential care and foster care.

812007 (2) NR 520 (HC).

82 The case was decided after the passage of the Children's Status Act, but before it came into force. The common law rule was found unconstitutional with effect from 21 March 1990 (the date of the Namibian Constitution). 
thus give some clues as to the depth of Namibian attitudes and beliefs about equality within and outside marriage.

The express objects of the act are to ensure that no child suffers discrimination or disadvantage because of the marital status of his or her parents (section 2). The act defines "marriage" broadly to include "a marriage in terms of any law of Namibia and includes a marriage recognized as such in terms of any tradition, custom or religion of Namibia". A "parent" is defined as a woman or a man in respect of whom parentage has been acknowledged or otherwise established.

The act provides for matters relating to access, custody and guardianship for children born outside marriage and, in part 4, grants equal rights to become the custodian parent to either parent (father or mother). However, one parent has to be the "sole custodian"; both parents may agree, orally or in writing, who should fulfil this role. ${ }^{83}$ Absent such agreement, or where the best interests of the child may be compromised or prejudiced, the person having physical custody of the child may apply to the children's court at district level for an interim order of custody. It is widely viewed that the act does not create a default position, where there is no agreement between the parents and no court application for interim custody has been launched. ${ }^{84}$ Hence, it has been argued that the common law position (which grants only the mother parental responsibilities and rights) survives.

The Children's Status Act does not define the principal incidents of parental authority, "custody" and "guardianship", which therefore retain their common law meaning. ${ }^{85}$ The act does define "sole custody" and "sole guardianship" (emphasis added) in section 1 as "the exercise of the respective rights, duties and powers [of custody and guardianship respectively] by one person to the exclusion of all other persons".

The act provides further, in section 13(3), that the persons who may seek an order for sole guardianship (to be granted to one parent or to some other person) include either parent, the child, someone other than the mother or the father of the child who is acting as the primary caretaker of the child, or a person authorized by the minister to act on behalf of the child. The last provision, particularly, fills the void brought about by the all too frequent deaths of guardians due to HIV/AIDS, leaving children below the age of majority in legal limbo. ${ }^{86}$

83 The bill initially proposed that the unmarried mother would have sole custody from birth, and that mothers and fathers would automatically acquire joint custody when the child reached seven years of age: D Hubbard "Gender and sexuality: The law reform landscape” in S LaFont and D Hubbard (eds) Unravelling Taboos: Gender and Sexuality in Namibia (2007, Legal Assistance Centre) 99 at 116.

84 Workshop for Namibian magistrates, September 2009, Swakopmund.

85 "Custody" relates to those aspects of parental authority which concern the day to day life of the child. Guardianship, in its narrow form, refers to the capacity to administer the child's estate and to represent the child in legal proceedings.

86 Sec 13(7) of the act provides, however, that the written consent of both parents is required for the adoption of the child, subject to the provisions permitting dispensing with consent, and for the removal of the child from Namibia for a period of more than 
The act formally places woman and men who parent children born outside marriage on an equal footing. The mother is no longer automatically sole custodian or guardian of the child, in the absence of a High Court order awarding the father both or some of these rights; instead, there is an assumed equality. However, juxtaposed against this is the "default position" that, if there is no agreement or application for interim custody, the common law position privileging the mother's rights prevails. In practice, it is also true that the majority of persons having physical custody of a child are likely to be mothers, who are then arguably not disadvantaged in the operation of the new statutory rules; this may in fact lead to a conclusion that, the illusion of formal equality notwithstanding, possession is nine tenths of the law.

However, should a case come to court, the act implies that both parents have equal rights to be considered for the award of custody and guardianship, with the child's best interests informing the final decision.

The Draft Namibian Child Care and Protection Bill ${ }^{87}$ contains an entire chapter on "proof of parentage and children born outside marriage" (chapter 6). The bill does not refer to the allocation of or incidence of custody or guardianship where a child is born in marriage, leaving this to be regulated, as before, by the common law and the Married Persons Equality Act 1996. The bill re-incorporates the provisions of the Children's Status Act, but envisages eliminating some of the practical problems by improving the procedures provided for under that act. The special status accorded to physical custody of the child is to be removed, in an attempt to avoid the deleterious effects of children being moved back and forth to obtain legal advantage: the "winning" custodian parent frequently being then spared the duty of paying maintenance. Social workers' reports will be required when custody and guardianship are disputed, to guide courts. The bill does not define custody or guardianship, or sole custody or sole guardianship (as did its predecessor). These terms will therefore bear their common law meaning.

\section{Custody}

Section 94 of the bill regulates custody; both parents of a child born outside marriage have equal rights to custody, and one parent must exercise custody. The identification of which parent this is to be should preferably occur through a written agreement, which may be registered. The effect of such an agreement is that the named parent has custody of the child and "has

contd

one year, unless a children's court orders otherwise. F !Owoses-/Goagoses "Custody and guardianship of children” in O Ruppel (ed) Children's Rights in Namibia (2009, Macmillan Education) 177 at 181 opines that this provision implies that both secs 13(3) and 13(7) seem to apply to children born within and outside marriage, and that sec 13(7) means that an order of "sole guardianship" does not divest the other parent wholly from parental authority: a residual power to consent to adoption or removal from Namibia is retained. This view seems correct.

Version dated 9 June 2010. 
the legal power to act in that capacity" (section 94(3)(b)). Where there is no agreement, an application may be made to a children's court, including by an unmarried father. A court will be required to order and consider a social worker's report before making any custody order, contested or not.

\section{Guardianship}

The bill provides that a person with custody of a child will also be the sole guardian of that child, unless a competent court upon application directs otherwise (section 96(1)(a)). In addition, the bill provides for the possibility of unmarried parents being named joint guardians of a child.

A person appointed as guardian for a child is to be known as a "legal guardian" (section 96(1)(b)); either parent, the child, someone acting as the caregiver of the child or a person authorized in writing by the minister to act on behalf of the child may apply to be so appointed. The provisions of the Children's Status Act requiring the written permission of both parents for the adoption of the child or removal from Namibia are retained (sections 96 (8) and 96(9)). Exceptions, such as where a parent cannot be located, or where consent is dispensed with, are statutorily provided.

\section{Access}

Access is an incident of parental authority at common law. For married parents, or parents who were married but get divorced, the common law position remains. However, the position for children born outside marriage is now regulated by section 14 of the Children's Status Act 2006.

The "sole custodian" scheme of the Children's Status Act presupposes that the parents of a child born out of wedlock are, by definition, not exercising joint custody: it is virtually presumed that they do not reside together. ${ }^{88}$ The first three subsections of section 14 provide:

"(1) Despite anything to the contrary contained in any other law, the noncustodian parent of a child born outside marriage has a right of reasonable access to such child unless a competent court, on application made to it, directs otherwise, but the right accrues only where the parent in question has voluntarily acknowledged parentage of the child.

(2) The right of access referred to in this section does not give the noncustodian parent the right to remove the child from the custodian parent's home or from any other place where the child resides without the consent of the custodian parent.

(3) Any access by the non-custodian parent is subject to the reasonable control of the custodian parent, or any other person who has been entrusted by the custodian parent with responsibility for the care and control of the child."

88 Proposals from civil society that would have provided for an option of joint custody were explicitly rejected in the debates surrounding the act (personal communication from Legal Assistance Centre, Windhoek). 
Section 97 of the proposed Child Care and Protection Bill re-enacts this by providing for a reasonable right of access to the parent of a child born outside marriage who does not have custody. The bill (unlike its predecessor) also defines access to include "all forms of electronic and telephonic contact conducive to fostering and maintaining a sound relationship between a child and the parent not having custody". ${ }^{89}$ Parties may agree on such access in a parenting plan. However, the right of access accrues "only where the parent in question has voluntarily acknowledged parentage of the child". ${ }^{90}$

\section{Maintenance}

At common law, biological parents were equally liable to maintain their children, and the discriminatory status of legitimacy or illegitimacy did not extend to the child's right to support. An unmarried father is liable for child support even where he enjoys no parental powers: guardianship, custody or access.

Maintenance is regulated by the Maintenance Act 9 of 2003, stipulating that both parents are liable to maintain a child if the child is unable to support him or herself (section 3). This applies regardless of whether "a child is born of a first, current or subsequent marriage" or whether the "parents are subject to any system of customary law which does not recognize both parents' liability to maintain a child", or are unmarried. Difficulties hamper the administration of this act and the intended protection of children therefore suffers. In public discourse, the payment of maintenance and access to children remain linked: custodian parents frequently want to refuse access to non-paying fathers, and non-resident fathers are reluctant to pay maintenance without access being granted.

Section 17 of the Children's Status Act provides that a distinction may not be made between a person born inside or outside marriage regarding the duty to maintain a child. The law therefore does not link maintenance of children conceptually to the acquisition or exercise of parental rights. In respect of the guidelines to be followed when a court is deciding on the award of custody or guardianship, section 3(2) of the Children's Status Act provides:

"When deciding what is in the best interests of the child, the children's court must consider the financial positions of the parents, together with the guidelines enumerated in subsection (1), but

(a) the financial positions of the parents are not the decisive factor; and

(b) the court may not approve an application for the custody of a child if the application is based on a desire to avoid the payment of maintenance in respect of that child".

Section 101 of the draft bill reiterates this.

89 Child Care and Protection Bill, sec 1.

90 Sec 97(9) provides that a person not having custody who has voluntarily acknowledged parentage of a child born outside marriage may apply to the children's court for an order granting a right of reasonable access to that child, with the parent or any other persons having custody being made a party to such proceedings. 


\section{Analysis of the equality dimensions of the Children's Status Act}

Are children's rights to non-discrimination upheld in the provisions adopted in 2006 with this aim in mind? First, because a requirement exists that one parent must have sole custody and, unless a court has directed otherwise, sole guardianship, illegitimate children are deprived of the benefit of joint parenting (albeit that the maintenance duty remains unaltered). The final version of the act was affected by civil society lobbying to avoid a "straight equality position", ie automatic joint custody rights for both parents of children born out of wedlock. Their concern was the position of vulnerable single mothers struggling to enforce maintenance commitments against absent fathers; it was argued that the absent father could in theory evade maintenance by exercising custody rights to remove the child from the mother's care. ${ }^{91}$

!Owoses-/Goagoses's conclusion that the ratification of international treaties has demanded a shift from a parent rights based approach to a child rights one has not been effected by the Children's Status Act. ${ }^{92}$ Her conclusion that the act ensures that "both parents have a common responsibility for the upbringing and development of the child" downplays the "winner takes all" approach that the act contains.

Secondly, the right to custody is still conceived as being that of a parent (against another parent), rather than the right of the child to parental care, although the latter is axiomatic when children are born in wedlock. The failure to provide in law for a "default" position where an agreement is not reached between the parents, or litigation is not launched, demonstrates a failure to consider the issue from the child's perspective.

Thirdly, the designation of which parent is to be the sole custodian, by agreement, is not required to take account of the best interests of the child; rather it reflects the respective power relations between the mother and the father. Although a court making a custody order is required to take account of the best interest of the child (section 11(5) of the Children's Status Act), the ex parte application procedure for the award of an interim custody order neither requires the voice of the child to be heard, nor is the court yet compelled or enabled to require any expert testimony as to what would

91 A substantive discussion of the parliamentary debates is provided by Hubbard "Gender and sexuality", above at note 83 at 118-19: "This final approach ... seems to bend over backwards to pretend that children have two identical parents, instead of a mother and a father. It is 'gender neutral' to a fault, despite the fact that child birth and child rearing are not gender-blind activities in Namibia." She asserts that debates around parental rights "bring to light male fears that equality for women will unfairly disadvantage men", which explains the "gender neutrality" in the face of social inequality and hardship experienced by single mothers.

92 !Owoses-/Goagoses "Custody and guardianship of children", above at note 86 at 182. 
be in the best interests of the child. ${ }^{93}$ These issues will be resolved in the new provisions of the draft bill.

The Children's Status Act did bring with it the benefit of accessibility, as the children's court at district level can adjudicate these matters instead of the High Court.

\section{ANALYSIS OF COMMON ISSUES IN THE THREE JURISDICTIONS}

This article began by questioning whether parental responsibilities and rights laws comply with international law demands. To this, the formal answer must be "no" in respect of Kenya and South Africa, and possibly "yes" in respect of Namibia.

On a positivist reading of equality, Kenyan laws currently discriminate against unmarried mothers, as they are impotent to claim child support unless the father of the child takes steps to acknowledge his responsibility. Further, that a child born out of marriage has no automatic claims or rights indicates a regime in which discrimination is legally sanctioned.

The South African Children's Act provides some remedial relief to unmarried fathers who are (or were) living with the mother at the time of the child's birth, or those who acknowledge paternity in a prescribed way and who contribute to a reasonable extent to the upbringing of the child. Yet fathers who do not meet the required criteria, especially those not living with the mother at the time of the child's birth, may well be compelled to prove their entitlement to a stake in the child's life, by their contribution to a child's upbringing or, if they are able to do so, by formally ensuring that their paternity is acknowledged. Fathers who are married to mothers at the time of the child's birth have no such hoops to jump through. Hence, discrimination on the grounds of marital status is patent. Importantly, however, this de facto unequal position was motivated by considerations of substantive (as opposed to formal) equality, as women are all too frequently the care-givers in South African society; they labour under a regime which makes securing maintenance from errant fathers very difficult.

Namibia's recent legislation sought to remedy the "equality gap" which existed for unmarried parents at common law by making formal equality the mandated default position, subject only to the fact that either the mother or the father must be awarded the bulk of the parental responsibility "prize", to the exclusion of the other. Practical problems have emerged, including a discriminatory regime for co-habiting couples exercising de facto joint responsibilities who must now choose which one of them will enjoy the whole package of parental responsibilities and rights.

Both the Namibian position of superficial equality and the South African position of limited equality mask the true provenance of the respective

93 The ex parte application procedure for interim custody has been completely removed in the draft bill. 
underlying policies. This, it can be argued, is supported by the Kenyan position which has seen the entrenchment of patently unequal treatment of children born out of wedlock. In the view of the authors, the underlying policy forces are twofold. The first is the reality of women's subordinate position in the region; secondly, because unmarried mothers bear the overwhelming burden of child rearing, their position would be weakened by a "straight equality" regime which gave fathers undue leverage and status by operation of law. Thus the Namibian custodian parent (father) can receive equal treatment, but the itinerant, part time father will only have contact.

The question is not merely one of gender power relations: the interests of the child are materially affected. Social security systems are fragile and the well-being and survival of the child frequently depends on the mother being able to enforce maintenance. This may not be enhanced by a position which places the unmarried parents in a completely equal position regarding the award of parental responsibilities and rights.

Less often articulated are assumptions about the enduring influence of customary law, which prevails in all three countries. Many parliamentarian lawmakers in all three countries have themselves grown up under customary law and express their own personal family ties in terms of customary law affiliation rules. Different forms of affiliation (especially ties to the mother's family) are often triggered by non-marital status; in the authors' view, the customary law backdrop has had an unacknowledged influence on the legislative schemes regarding parental responsibilities described in this article. The resilience of customary law in mediating the (inexorable) drive to equality in the face of strong international law commitments seems to require a more nuanced approach to assimilating customary law sensitively.

A more pragmatic approach to the interpretation of non-discrimination in the context of international children's rights law might be developed. This interpretation would not proceed from a purely positivist stance that absolute equality between children born in and out of wedlock is the expected norm; legislation which masks differences under the guise of formal equality is not the optimal way to domesticate international human rights law. Such a theory of substantive equality would recognize that the best interests of children should not be sacrificed on the altar of formal equality. The reality is their actual experience of being cared for by impoverished single mothers who struggle to enforce maintenance.

Such an understanding of equality might highlight that statutes which permit differences in family affiliation laws are permissible to the extent that they do not foster de facto discrimination (as experienced by the child) or facilitate different outcomes for the child (eg where children born out of wedlock suffer on account of the non-payment of maintenance, as in Kenya). Hence, a position (such as in Namibia and South Africa) which does not relieve the father of the child born out of wedlock from the responsibility of child support is to be preferred. Moreover, customary law values can infuse the development of children's rights law to the benefit of children and enhance a culturally 
sensitive interpretation of international law principles, to the extent that they do not enable outcomes for children to differ unfairly.

\section{CONCLUSION}

The position of children born out of wedlock has changed through recent law reform in the three countries considered in this article. However, the concerns of fathers' lobby groups, gender activists and parliamentarians themselves have affected the shape and form of the final laws. There has been ongoing litigation in Kenya, and in Namibia where courts struggle to give effect to the 2006 provisions. The South African provisions have yet to be elaborated by the courts. A "straight equality" position between unmarried mothers and fathers does not enjoy public support, as it may exacerbate the unequal de facto position of single mothers. Nevertheless, delinking the obligation of biological fathers to pay maintenance from their acquisition of parental responsibility, as in South Africa and Namibia, appears preferable to the current Kenyan position which permits fathers to choose whether they wish to assume responsibilities. 
Copyright of Journal of African Law is the property of Cambridge University Press and its content may not be copied or emailed to multiple sites or posted to a listserv without the copyright holder's express written permission. However, users may print, download, or email articles for individual use. 